Journal of Applied Pharmaceutical Science Vol. 3 (09), pp. 024-028, September, 2013

Available online at http://www.japsonline.com

DOI: $10.7324 /$ JAPS.2013.3905

ISSN 2231-3354 (cc) BY-NC-SA

\title{
In vitro AFM evaluation of Streptococaus mutans membrane exposed to two mouthwashes
}

\author{
Edilaine A. C. Orasmo ${ }^{1}$, Walter Miyakawa ${ }^{2 *}$, Choyu Otani ${ }^{3}$, Sonia Khouri ${ }^{1}$. \\ ${ }^{1}$ Faculty of Health Sciences, Vale do Paraíba University, Sao Jose dos Campos, Brazil. \\ ${ }^{2}$ Photonics Division, Institute for Advanced Studies, Sao Jose dos Campos, Brazil. \\ ${ }^{3}$ Physics Department, Aeronautic Technological Institute, Sao Jose dos Campos, Brazil.
}

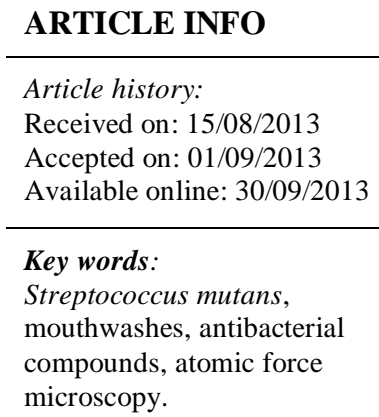

\begin{abstract}
Streptococcus mutans is the primary microorganism of the dental plaque, which causes the caries disease. In addition to tooth brushing, oral care products are usually recommended by dentists to reduce and prevent the plaque formation. The objective of this work was to assess via atomic force microscopy the Streptococcus mutans membrane exposed to two mouthwashes, one containing triclosan, and the other, phenolic essential oils. $S$. mutans were cultured in brain and heart infusion during 48 hours at $37^{\circ} \mathrm{C}$. The pellets were harvested by centrifugation ( $2500 \mathrm{rpm}, 3 \mathrm{~min}$ ), and re-suspended in $4 \mathrm{~mL}$ mouthwash. One minute later, the bacterial cells were washed twice times by centrifugation $(2500 \mathrm{rpm}, 3 \mathrm{~min})$ using saline solution $(0.9 \% \mathrm{NaCl})$. The cell mass was gently spread over clean glass coverslip and evaluated by atomic force microscopy, in dynamic mode. For microorganisms not exposed to mouthwashes, images showed clustered microcolonies with round-shaped cells in typical string arrangement. Measured mean diameter varied between $0.6 \mu \mathrm{m}$ and $1.0 \mu \mathrm{m}$. Exposure to phenolic essential oils caused no perceptible alterations in the bacterial cells. However, after exposure to triclosan, cell membranes were slightly wrinkled, probably due to the structural perturbations caused in the membrane permeability.
\end{abstract}

\section{INTRODUCTION}

Streptococcus mutans is the prevalent microorganism of the dental biofilm (plaque) and the primary pathogenic agent responsible for the caries disease. Tooth brushing and flossing still are the best ways to prevent and control the plaque formation. Mouth rinses are also effective and recommended, acting as chemical complements of the oral hygiene.

Nowadays, dozens of mouthwashes are available on the market, each one based on different chemical or phytotherapic formulations. The antimicrobial effects of these agents are well established, though images of the $S$. mutans membrane exposed to the mouth rinse active compounds are scarcely found in the literature. It is known that vital metabolic activities of microorganisms are strongly related to the protection and transport capabilities of the cell membrane. Hence, the visualization of ultrastructural alterations induced by antibacterial compounds on

\footnotetext{
* Corresponding Author

Walter Miyakawa, Trevo Coronel Aviador José Alberto Albano do

Amarante, 1, Sao Jose dos Campos, SP, Brazil Zip code: 12228-001

Phone: +55 12 3947-5415, Fax: +55 12 3944-1177
}

the bacterial membrane will not only contribute towards a more comprehensive knowledge of the biochemical mechanisms of oral antiseptics, helping in the establishment of a safer and lower critical dosage of active drugs, but also will benefit other processes, for which the cell membrane has a fundamental part, like in the photodynamic antimicrobial therapy (Melo et al., 2013; Nunez et al., 2010). The AFM has been shown to be appropriate to not only ultrastructural evaluations of biofilm surfaces, but also to a single bacteria cell. Teixeira et al. (2013), for example, assessed the alterations on bacterial membranes induced by betacyclodextrinchlorhexidine via AFM. The authors observed external membrane disruption, with exposure of partially disintegrated periplasmic fragments and cytoplasmic fluid loss.

The purpose of this work was to assess, by atomic force microscopy, the morphologic and topographical characteristics of Streptococcus mutans cell membranes, after exposure to mouthwashes containing triclosan and a mixture of phenolic essential oils (thymol, eucalyptol, menthol \& methyl salicylate), during one minute. 


\section{EXPERIMENTAL}

\section{Bacterial strains and growth conditions}

The Gram-positive bacterial strain used in this study was the ATCC 25175 Streptococcus mutans. This strain was grown in brain and heart infusion broth (DIFCO Lab., Detroit, Mich.) supplemented with $20 \%$ saccharose. The culture was incubated at $37^{\circ} \mathrm{C}$ for 48 hours. After that, the bacterial suspension was divided into three groups, each one with three tubes containing $1.5 \mathrm{~mL}$ of the inoculum.

A centrifugation procedure at $2500 \mathrm{rpm}$ for 3 minutes was used to harvest the cells. For each control tube, the cell mass was re-suspended in $4 \mathrm{~mL}$ saline solution $(0.9 \% \mathrm{NaCl})$. Each test tube have their pellets re-suspended in $4 \mathrm{~mL}$ mouthwash, so as to have three of them with triclosan, and the three others, with essential oils based mouth rinse. Precisely after one minute, bacterial cells were washed twice by centrifugation at $2500 \mathrm{rpm}$, during 3 minutes, using $0.9 \%$ saline solution. Each time, the supernatant was carefully discarded, retaining the cells at the tube bottom. After the last centrifugation, the cell mass was gently spread over clean glass coverslips using $10 \mu \mathrm{L}$ inoculating loops, and dried at room temperature in covered Petri dishes for a few minutes. The samples were then immediately moved to the microscopy analyses.

\section{Atomic force microscopy analyses}

The samples were evaluated in the SPM $9500 \mathrm{~J} 3$ (Shimadzu Corp. Inc., Japan) atomic force microscope, in dynamic operation mode at low scanning rate $(0.5-1.0 \mathrm{~Hz})$, using I-shaped cantilevers $(330 \mathrm{kHz}$ resonance frequency, $42 \mathrm{~N} / \mathrm{m}$ elastic constant) with conventional $\mathrm{Si}_{3} \mathrm{Ni}_{4}$ tips (10-15 $\mu \mathrm{m}$ nominal curvature radius).

AFM software facilities (Data Processing Software, Shimadzu SPM-9500 series, Shimadzu Corp. Inc., Japan) were used to evaluate shape, and quantify dimensions and topography of the microorganisms colonies.

\section{RESULTS AND DISCUSSIONS}

Figure 1 shows typical topographical AFM images of control Streptococcus mutans cells, in bidimensional visualization with (a) $20 \mu \mathrm{m} \times 20 \mu \mathrm{m}$ and (b) $5 \mu \mathrm{m} \times 5 \mu \mathrm{m}$ scanning area, respectively. Bacterial cells were round-shaped and clustered in micro-colonies with typical string arrangement.

The atomic force microscope (Meyer et al., 2003; Magonov et al., 1996; Bhushan et al., 2004) was developed by Binning et al., in 1986. As well described by Morris et al. (2010), images are obtained "touching" the sample instead of looking at it. To touch the sample, the AFM uses a very sharp tip, localized at the end of a flexible cantilever. As this tip scans the sample surface, the cantilever deflects following the surface topography. The cantilever deflection is detected by measuring the displacement of a reflected laser beam off the cantilever onto a photodetector. In a computer, the photodetector signal is converted in spatial coordinates $x-y-z$, generating each point of the image. Thanks to this "tactile" way of obtaining images, quantitative information is in fact extracted. From the spatial coordinates, calculations, measurements, graphics and analyses of the whole image or its subareas can be readily done. In Figure 2 (b), it is shown the surface profile of two cells from the control sample micrograph displayed in Figure 2 (a). These profile curves delineate the cells membranes, emphasizing their smooth texture and measured diameters in the range $0.6 \mu \mathrm{m}-0.7 \mu \mathrm{m}$. Our results presented excellent agreement with the literature (Melo et al., 2013; Cross et al., 2006).

Another unquestionable advantage of the AFM is related to sample preparation. Staining, thin conductor film deposition, or vacuum are unnecessary and samples are preserved in their natural state. This characteristic is particularly attractive to microbiology, allowing the evaluation of the same sample before and after some treatment. The AFM has been used to study Streptococcus mutans biofilm formation ( $\mathrm{Hu}$ et al., 2011), and adherence in resin and ionomer surfaces (Kimyai et al., 2011). Morphological alterations in cell membrane induced by green tea catequine (Cuia et al., 2012) and by photodynamic therapy (Melo et al., 2013; Nunez et al., 2010) are also current examples of AFM applications in microbiology.

In Figure 3, it is shown $S$. mutans cells after exposure to phenolic essential oils based mouth rinse. Bacterial cells keep on presenting spherical shape and linear micro-colonies arrangement. In this image, measured diameters varied in the range $0.7 \mu \mathrm{m}$ e 1.1 $\mu \mathrm{m}$. Analyzed profile curves revealed no significant texture change in cell membranes compared to the control sample.

After the application of triclosan based mouthwash, Streptococcus mutans cells clearly preserved the round-shape aspect, with $1.0 \mu \mathrm{m}$ diameter, and the linear arrangement, as can be viewed in Figure 4. However, cell membranes were slightly wrinkled (Figure 4 (c)), giving evidence of morphological modifications produced by the triclosan on the membrane surface. To the best of our knowledge, images of ultrastructural membrane alteration after mouthwash antibacterial compounds interaction are rarely found in the literature, though of unquestionable importance to help in elucidation of mechanisms of interaction between drugs and microorganisms.

Gonçalves et al. (2010) reported protein denaturation, changes in membrane permeability of Gram-negative bacteria, and cytoplasm cation chelation induced by phenolic essential oils in alcoholic vehicle, resulting in enzyme inactivation. For Moreira et al. (2009), phenolic compounds can both inhibit the enzymatic action or rupture the cell membrane. In the present work, after one minute of exposure time, the AFM images (Figure 2) showed that bacterial cells have kept the spherical shape and the linear colony arrangements. Membrane rupture was not observed. Our results demonstrated that the enzymatic inactivation associated with changes in membrane permeability preserved entirely the cell morphology of bacteria. Of course, other exposure times will be opportunely tested, though it should also be emphasized that 
people are supposed to rinse their mouth for 30 seconds, twice a day, which means one minute of total daily exposure time. Triclosan is a non-ionic, synthetic phenolic substance with low level of toxicity and wide spectrum activity, being effective against Gram-positive, Gram-negative, and anaerobic microorganisms, besides Candida fungi and spores (Moreira et al., 2009). It is a membrane-active agent which causes structural perturbations, anti-enzyme actions, glycolysis inhibition and membrane disruption (Phan and Marquis, 2006;

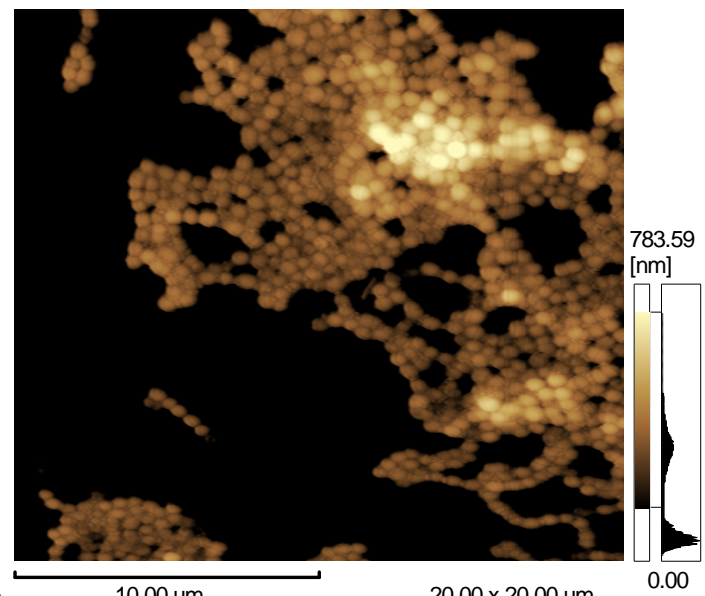

(a)

10.00 um

$20.00 \times 20.00$ um
Torres et al., 2000). Cellular retraction is an evidence of loss of intracellular components, and membrane blebbing or wrinkling can appear as a consequence. In Figure 5, it is shown a magnification of an area of Figure 4 (b), where wrinkles can be easily viewed. Profile curves in Figure 4 (c) have corroborated the visual observation. From these results, we concluded that after one minute of exposure time, triclosan based mouth rinse have caused cell membrane disorganization and retraction on $S$. mutans bacteria.

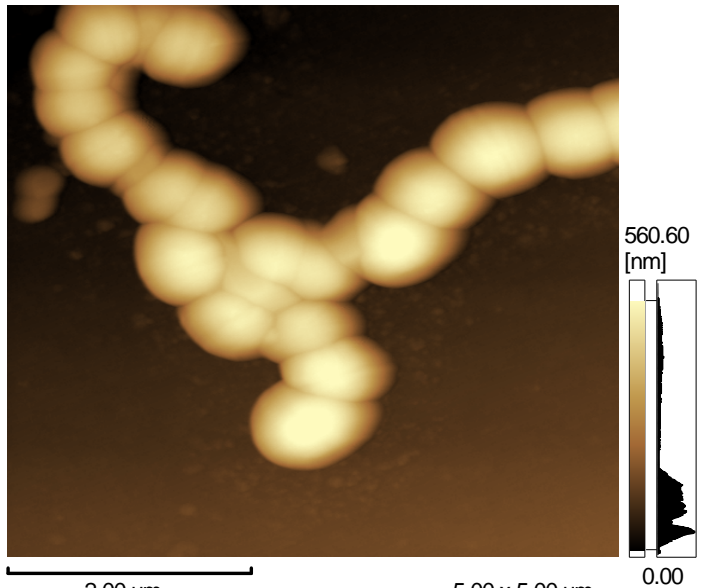

$5.00 \times 5.00$ um

(b)

Fig. 1: Typical AFM images of Streptococcus mutans, in bidimensional visualization, with (a) $20 \mu \mathrm{m}$ x $20 \mu \mathrm{m}$ and (b) $5 \mu \mathrm{m}$ x $5 \mu \mathrm{m}$ scanning area, respectively.
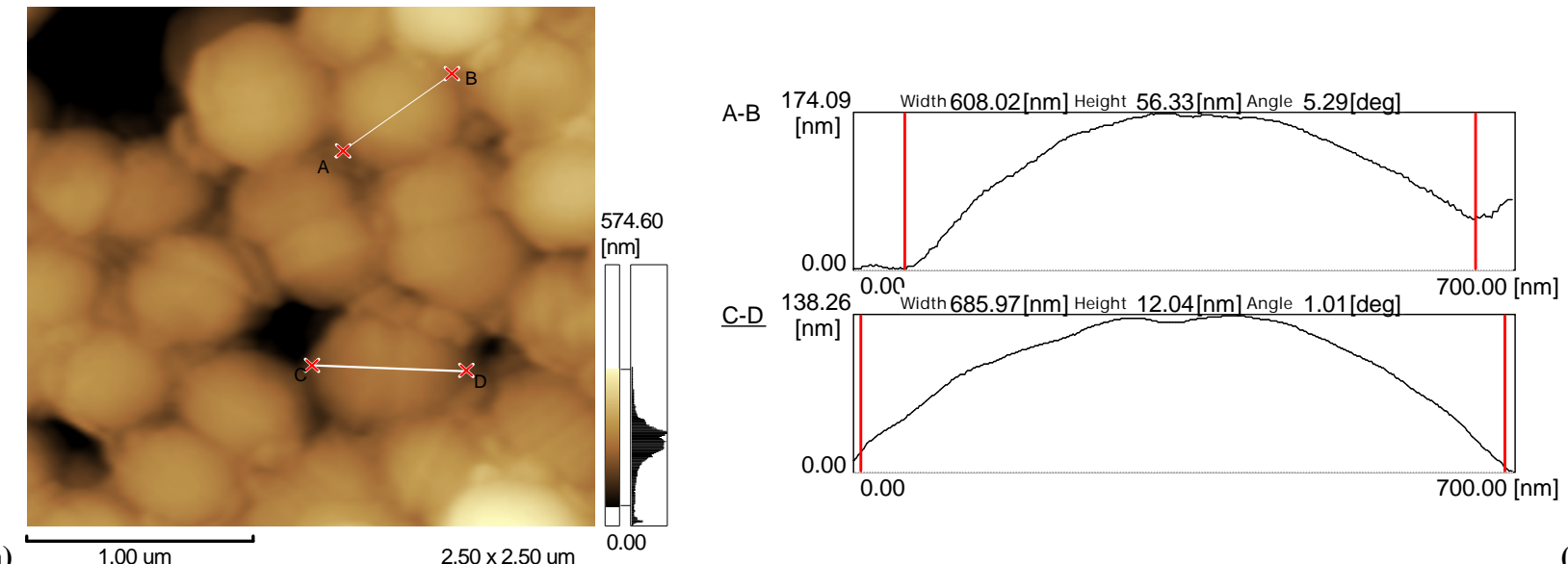

(a)

1.00 um

$2.50 \times 2.50$ um

(b)

Fig. 2: (a) AFM image of Streptococcus mutans, with $2.50 \mu \mathrm{m} \times 2.50 \mu \mathrm{m}$ of scanning area and (b) profile curves of two bacterial cells, for dimensional and topographic analyses.

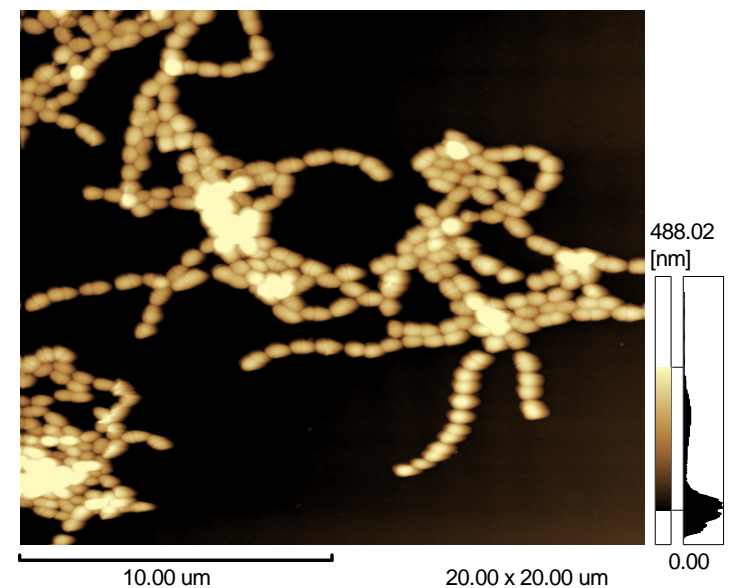

(a)

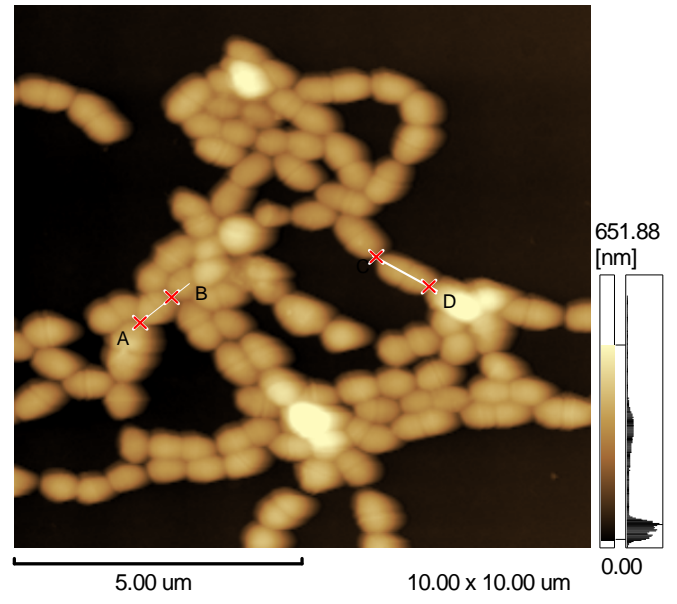

(b)

Fig. 3: .... 


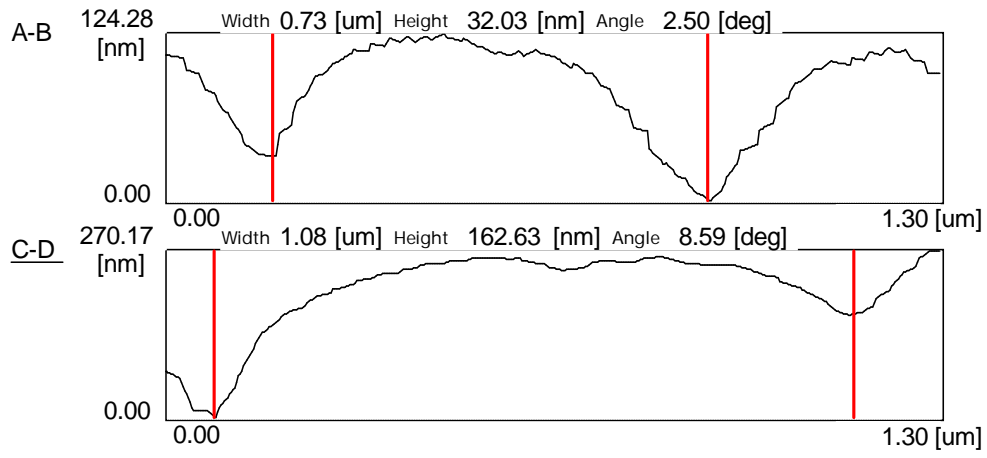

(c)

Fig. 3: AFM images of Streptococcus mutans cells after phenolic essential oils based mouth rinse exposure, with (a) $20 \mu \mathrm{m} \times 20 \mu \mathrm{m}$ and (b) $10 \mu \mathrm{m} \times 10 \mu \mathrm{m}$ scanning area, and (c) profile curves of two cells, for dimensional and topographic analyses.

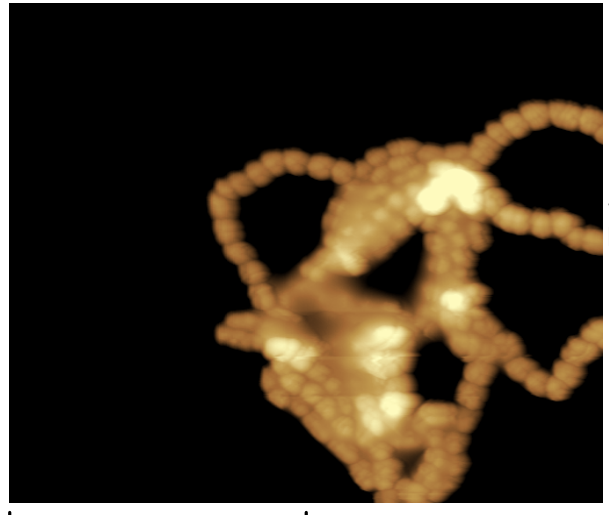

10.00 um

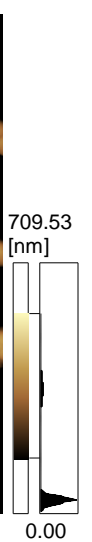

$20.00 \times 20.00$ um

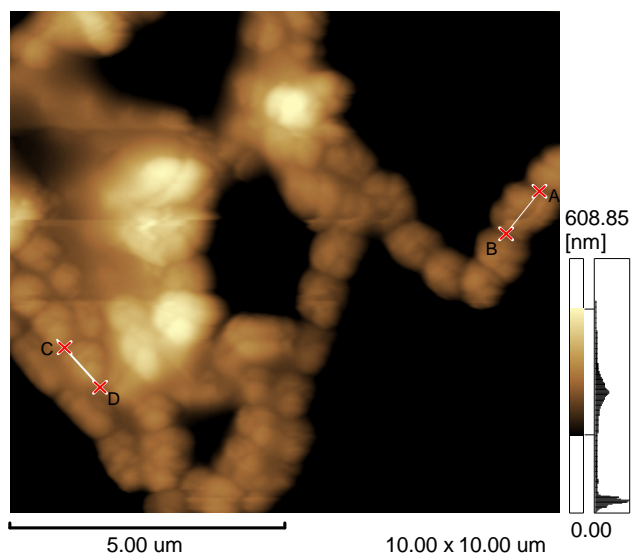

(b)

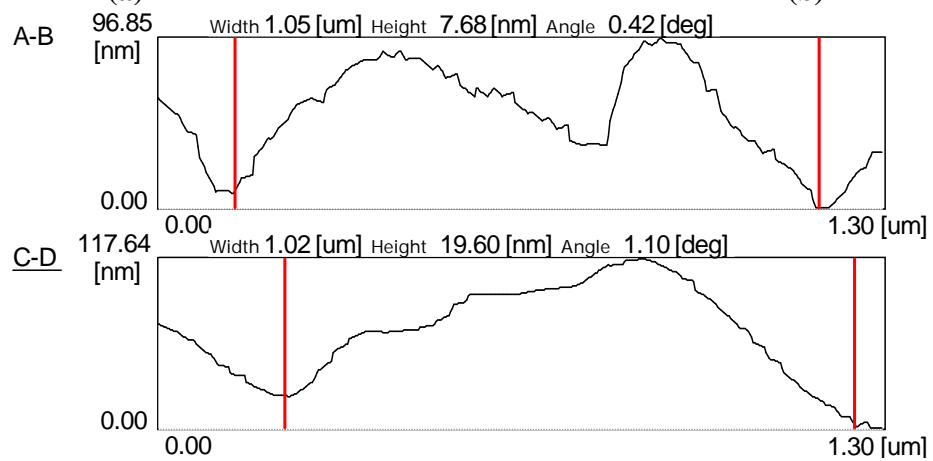

(c)

Fig. 4: AFM images of Streptococcus mutans after triclosan based mouthwash exposure, with (a) $20 \mu \mathrm{m} \times 20 \mu \mathrm{m}$ and (b) $10 \mu \mathrm{m} \times 10 \mu \mathrm{m}$ scanning area, and (c) profile curves of two cells, for dimension and topographic analyses.

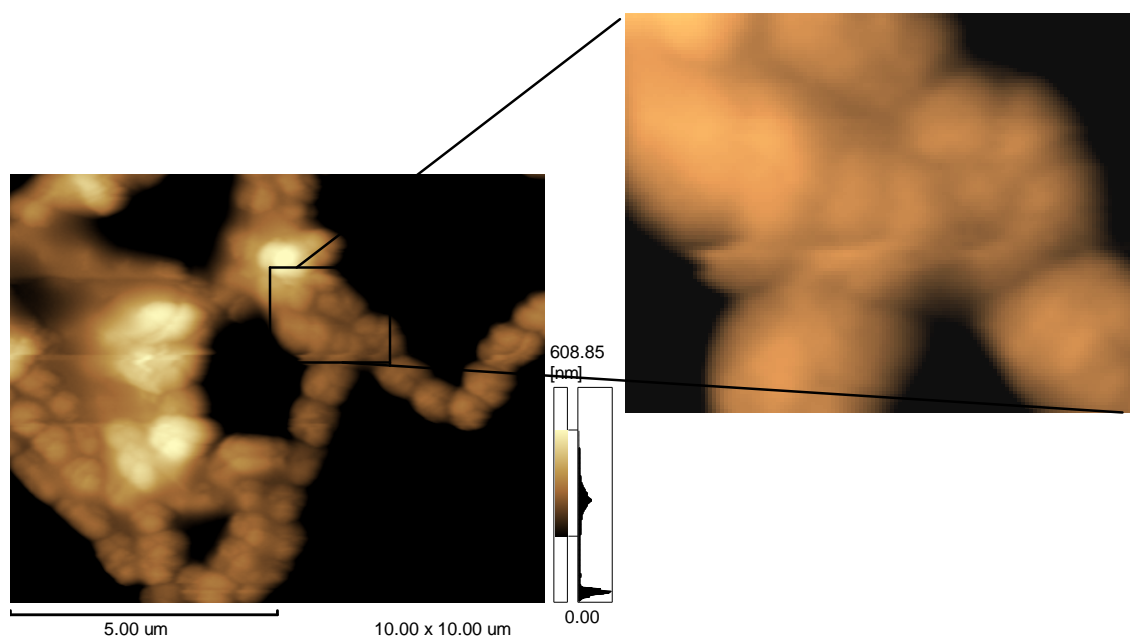

Fig. 5: Magnification of a small subarea of an AFM image of Streptococcus mutans after triclosan based mouthwash exposure, showing membrane wrinkling. 


\section{CONCLUSION}

The atomic force microscopy is a powerful instrument for microbiology, as morphological and topographic alterations in cellular membrane ultrastructure can be in fact measured, and not only inferred by visual inspection. From our AFM observations, it was concluded that immersion for one minute in phenolic essential oils based mouthwash has not altered $S$. mutans cell membrane morphology. Conversely, triclosan caused cellular retraction, evidenced by membrane wrinkling. Obviously, further studies should be opportunely conducted to more comprehensive analyses of the systematic effects of antibacterial compounds on the microorganism membrane ultrastructure. Some issues should still be investigated. For example, will the cell membrane become more wrinkled as the exposure time is increased? Or is it influenced by the antibacterial compound concentration? Is the cell membrane elasticity changed during this process?

\section{ACKNOWLEDGEMENT}

To the Laboratory of Surface Characterization, Aeronautic Technological Institute, for the AFM facility and to NUFABI - UNIVAP, for the microbiology infrastructure.

\section{REFERENCES}

Bhushan, B. 2004. Springer Handbook of Nanotechnology, Berlin Heidelberg (DE), Springer-Verlag.

Binnig G, Quate CF, Gerber Ch. Atomic force microscope. Phys. Rev. Lett. 1986; 56:930-933.

Cross SE, Kreth J, Zhu L, Qi F, Pelling AE, Shi W, Gimzewski $\mathrm{JK}$. Atomic force microscopy study of the structure-function relationships of the biofilm-forming bacterium Streptococcus mutans. Nanotechnol. 2006; 17:S1-S7.

Cui Y, Oh YJ, Lim J, Youn M, Lee I, Pak HK et al. AFM study of the differential inhibitory effects of the green tea polyphenol (_)epigallocatechin-3-gallate (EGCG) against Gram-positive and Gramnegative bacteria. Food Microbiology 2012; 29:80-7.

Gonçalves EM, Portela EP, Aragão PRC, Ponte TC, Lima DLF. Grau de conhecimento dos cirurgiões dentistas na prescrição de colutórios e dentifrícios. R. Periodontia, 2010; 20(4):51-55.

Hu Y, Zhang J, Ulstrup J. Investigation of Streptococcus mutans biofilm growth on modified $\mathrm{Au}(111)$-surfaces using $\mathrm{AFM}$ and electrochemistry. J. Electroanal. Chem. 2011; 656(1-2) SI: 41-9.

Kimyai S, Lotfipour F, Pourabbas R, Sadr A, Nikazar S, Milani M. Effect of two prophylaxis methods on adherence of Streptococcus mutans to microfilled composite resin and giomer surfaces. Medicina Oral Patologia Oral y Cirugia Bucal 2011; 16(4):E561-7.
Locatelli CI, Englert GE, Kwitko S, Simonetti AB. Aderênia bacteriana in vitro a lentes intraoculares de polimetilmetacrilato e de silicone. Arq. Bras. Oftalmol. 2004; 67:241-8.

Lucena MCM, Gomes RVS, Santos MCMS. Assessment surface roughness of the flowable resin filtek Z 350 3M ESPE exposed to mouthrinses with and without alcohol. Odontol. Clín. Cient., 2010; 9(1):59-64.

Magonov SN, Whangbo MH. 1996. Surface Analysis with STM and AFM: Experimental and Theoretical Aspects of image Analysis, Wiley-VCH, New York (USA).

Melo MAS, Rolim JPML, Zanin ICJ, Barros EB, Costa EF, Rodrigues LKA. Characterization of antimicrobial photodynamic therapytreated Streptococci mutans: an atomic force microscopy study. Photomed. Laser Surg. 2013; 31(3):105-9.

Meyer E, Hug HJ, Bennewitz. R. 2003. Scanning Probe Microscopy: The lab on a tip, Berlin Heidelberg (DE), Springer Verlag.

Moreira ACA, Pereira MHQ, Porto MR, Rocha LAP, Nascimento BC, Andrade PM. Avaliação in vitro da atividade antimicrobiana de antissépticos bucais. R. Ci. Méd. Biol. 2009; 8(2):153161.

Morris VJ, Kirby AR, Gunning AP. 2010. Atomic force microscopy for biologists. $2^{\mathrm{a}}$ ed. London (UK): Imperial College Press.

Nascimento PFC. 2005. Avaliação in vitro do potencial antimicrobiano do óleo essencial de Hyptis pectinata (L.) Poit. e de colutórios sobre os Streptococcus mutans [dissertação]. Sergipe: Universidade Federal de Sergipe, Faculdade de Medicina.

Neves BRA, Vilela JMC, Andrade MS. Microscopia de varredura por sonda mecânica: uma introdução. Cerâmica 1998; 44(290): 212-9.

Nunez SC, Ribeiro MS, Garcez AS, Miyakawa W. Assessment of photodynamic damage on Escherichia coli via atomic force microscopy. In: Proc. of SPIE Biophotonics: Photonic Solutions for Better Health Care II, 2010; 7715:77151L1-8.

Phan T-N, Marquis RE. Triclosan inhibition of membrane enzymes and glycolysis of Streptococcus mutans in suspensions and biofilms. Can. J. Microbiol. 2006; 52:977-983.

Teixeira KIR, Araujo PV, Neves BRA, Mahecha GAB, Sinisterra RD, Cortes ME. Ultrastructural changes in bacterial membranes induced by nano-assemblies beta-cyclodextrinchlorhexidine: SEM, AFM, and TEM evaluation. Pharm. Develop. Technol. 2013: 18:600-608.

Torres CRG, Kubo CH, Anido AA, Rodrigues JR. Agentes antimicrobianos e seu potencial de uso na odontologia. Pós-Grad Rev. Fac. Odontol. São José dos Campos 2000; 3(2):43-52.

\section{How to cite this article:}

Edilaine A. C. Orasmo, Walter Miyakawa, Choyu Otani, Sonia Khouri, In vitro AFM evaluation of Streptococcus mutans membrane exposed to two mouthwashes. J App Pharm Sci, 2013; 3 (09): 024-028. 